\title{
ULTIMUS ROMANORUM
}

THE passing of Professor Priestley Smith in his 88th year is truly the breaking of a link with the past. For more than 50 years his voice has been a dominant factor in all that concerns British Ophthalmology; and we, of the Brit. Jl. of Ophthal., in particular owe him a deep debt of gratitude.

Mr. Priestley Smith began life as an engineer, and it was a happy day for medicine when he decided to take up eye work. After having been house surgeon to the Birmingham Eye Hospital for two years, he became, in 1874, a clinical assistant to Sir William Bowman at Moorfields, and then returned to Birmingham.

His work, on glaucoma in the late seventies of last century has stood the test of time and is recognised the world over as one of the few positive facts in a realm of speculation as to the causation of this disease.

An original member of the Ophthalmological Society of the United Kingdom, he was at the time of his death the senior pastpresident. Innumerable honours have been awarded to him, culminating last year in the Gullstrand Gold Medal of the Swedish Medical Society; but what he probably valued most of all was the affectionate regard in which he was held, not only in Birmingham but throughout the British Empire, wherever ophthalmology is taught. And now that his race has been run, we may, in this tribute, echo the words of Marc Antony of Brutus.

"This was the noblest Roman of them all."

\section{CONCILIUM OPHTHALMOLOGICUM}

THE Fourteenth International Congress of Ophthalmology opened in Madrid on Sunday, April 16. A meeting of the International Council had taken place the evening before, and at 10 a.m. in the amphitheatre of the University the Inaugural Session opened under the patronage of His Excellency Don Niceto Alcalá Zamora, President of the Spanish Republic, in the presence of the Ministers of Public Instruction and of Marine, the Director of Hygiene, the Rector of the University, the Dean of the Faculty of Medicine and over six hundred members of the Congress.

Professor Van der Hoeve, as President of the International Council, opened the proceedings with his usual enviable polyglot eloquence. He spoke in turn in French, English, German, Italian and Spanish with that grace and charm of manner which thase of 